\title{
11 de setembro: das Reformas aos atentados
}

\section{September 11: from reforms to attacks}

O presente artigo pretende mostrar as ideias e acontecimentos que serviram de base ao líder da Al-Qaeda Osama bin Laden. Através da Escola Hanbali e das Reformas no mundo islâmico, surgiram teóricos que são peças fundamentais para entender os desdobramentos de grupos como a Al-Qaeda. Dessa forma, o artigo se debruça sobre os aspectos históricos e religiosos que perpassam esse meio. Através das obras do teórico Sayyid Qutb, faz-se uma abordagem a respeito do conceito de jihad, sobre o seu significado e como a questão é abordada pela Al-Qaeda.

Palavras-chave: Bin Laden. Jihad. Onze de setembro.

\section{Abstract}

This article aims to show the ideas and events that served as the basis for Al-Qaeda leader Osama bin Laden. Through the Hanbali School, and Reforms in the Islamic world, theorists who are fundamental to understanding the unfolding of groups such as Al-Qaeda emerged. Thus, the article focuses on the historical and religious aspects that permeate this medium. An approach through the works of the theorist Sayyid Qutb is made to the concept of jihad, with its meaning, and also how it is approached by Al-Qaeda.

Keywords: Bin Laden. Jihad. September $11^{\text {th }}$.

\section{I n t rod u çã o}

Os conflitos que envolvem o Islã e abordam temas como violência, terrorismo, guerras e manifestações, entre outros, no Oriente Médio, estão na pauta de discussões cotidianas e acadêmicas. Os ataques de 11 de setembro de 2001, nos Estados Unidos, marcaram o olhar contemporâneo do ocidente sobre o Islã, sobretudo da mídia, que, desde então, tem concentrado esforços em divulgar notícias de conflitos que, apesar de envolverem temas políticos e econômicos, podem apresentar também questões religiosas como pano de fundo. 
Vinte anos após um dos maiores atentados da história, o de 11 de setembro de 2001, ainda é possível enxergar o tamanho de seus desdobramentos, que vão desde o aparecimento do islã na mídia até o surgimento de guerras, como no Iraque e Afeganistão. Porém, antes de passar por esses fatos é preciso perpassar por alguns conceitos que são trabalhados na conjuntura atual, como jihad e fundamentalismo, e pelas Reformas, como o Wahhabismo e salaffyya, pontos que possuem grande relevância para o entendimento do contexto da criação do grupo Al-Qaeda tempos antes dos atentados.

É importante ressaltar que o primeiro contato entre Oriente e Ocidente - no caso, as terras islâmicas com os Estados Unidos e Europa -, não acontece nos atentados; foram vários processos históricos que devem ser conhecidos e apresentados. Dessa forma, a partir dos autores Albert Hourani e Karen Armstrong, será feito um percurso histórico que pretende levantar questões acerca desse contato entre Oriente e Ocidente. falado também sobre a modernidade a partir dos autores Peter Berger e Anthony Giddens.

Na segunda parte do artigo, ao tratar das Reformas, serão usados os estudos do autor Paulo Gabriel Hilu e do teórico Sayyid Qutb para trazer o campo de ideias necessárias para se pensar nos desdobramentos posteriores.

Finalmente, na última parte será feita uma análise das ideias apontadas por Sayyid Qutb, que reaparecem em outros personagens e conjunturas, como em Abdullah Azzam e Mohamed al Maqdisi, juntamente com o contexto de criação da Al-Qaeda. Nessa parte serão utilizadas as cartas de Osama bin Laden juntamente com as críticas e análises de autores como Tariq Ramadan.

\section{Modernidade ecrise de sentido}

Nesse tópico serão abordados conceitos como o fundamentalismo, relacionado a questões históricas e à modernidade. Desconstruir e trazer considerações que eliminam a relação direta entre fundamentalismo e islã se faz essencial para compreensões que virão adiante.

Atualmente é comum que os conflitos envolvendo os contextos muçulmanos sejam relacionados à noção de "fundamentalismo religioso". O fundamentalismo, de acordo com Teixeira (2007), é um fenômeno marcadamente moderno, expressão de uma reação às influências da globalização e do pluralismo. O termo foi aplicado pela primeira vez na passagem do século XIX para o século XX e fazia referência a um movimento teológico protestante que nasceu nos Estados Unidos como uma forma de reação ao modernismo e liberalismo teológico, além de assumir ideias de inerrância e de anti-ecumenismo (Teixeira, 2007).

O fenômeno do fundamentalismo, diante do pluralismo e da ameaça globalizadora, reage, afirmando a tradição, e rejeita todo e qualquer engajamento dialogal com a modernidade (Berger, 2012). Em suas raízes há sempre o sentimento de insegurança, desorientação ou anomia que são resultantes de uma dinâmica modernizadora. Nesse sentido, parece constituir uma resposta para todas as frustrações da vida moderna. É uma realidade nas religiões nos tempos modernos, que surge sempre como uma reação aos problemas da modernidade e corresponde às lógicas profundas da sociedade moderna e das religiões. De acordo com Peter Berger (2012), o fundamentalismoé um esforço para restaurar a certeza ameaçada.

Como se pode ver, o conceito de fundamentalismo não foi criado em um contexto islâmico. Armstrong (2001, p. 10) relata que "[...] o fundamentalismo é um fato global e em toda religião importante tem surgido como resposta aos problemas de nossa modernidade". Deve-se, então, repensar essa relação direta entre fundamentalismo e Islã, já que essa reação ocorre em todo o mundo e em todas as religiões. 
Neste sentido, a tendência fundamentalista, como reação à modernidade, ocorre no Islã dentro do contexto da colonização europeia nos países árabes e no norte da África, sobretudo por volta dos anos de 1960 e 1970, afirma Armstrong (2001).

De acordo com Hourani (2013), a invasão europeia teve início pela Índia no século XVIII. Em 1798, as tropas de Napoleão Bonaparte ocuparam o Egito e, logo após, nos 100 anos seguintes, as potências europeias colonizaram vários países islâmicos: Argélia em 1830, Tunísia em 1881, Egito em 1882, Sudão em 1889, Líbia e Marrocos em 1912. Além disso, durante a Primeira Guerra, estabeleceram mandatos no Líbano, Síria e Palestina. Ataturk, (militar revolucionário e primeiro presidente da Turquia), contudo, conseguiu evitar o domínio europeu criando o Estado Independente da Turquia e se tornando seu primeiro presidente. Posteriormente, por volta de 1920, afirma o historiador Hourani (2013), o controle militar da Grã-Bretanha e da França no Oriente Médio estava mais forte do que nunca, a estrutura política que a maioria dos países árabes tinham se desintegrou e a ideia de independência do Islã em conjunto com as pretensões de califado desapareceram na história.

O pensamento ocidental moderno se construiu a partir de um ideal de conhecimento e organização social e política que legitimou o subjugo de outras culturas ao longo de séculos de colonialismo. Como afirma Said (2012, p. 32): "[...] a relação entre o Ocidente e o Oriente, é uma relação de poder, de dominação, de graus variáveis de uma hegemonia complexa". Nas histórias do período de colonização e até nos dias atuais é possível se deparar com o conceito de modernidade. Edward Said, em "Orientalismo", questiona a noção ocidental de modernidade, do que é moderno. Para ele, o que se julga ser moderno é uma verdade ocidental; uma visão que foi imposta, e a maioria dos fatos conhecidos sobre o mundo árabe se baseia nisto: um olhar ocidental.

Said (2012) faz uma severa crítica à forma como o muçulmano árabe é esteriotipado como subalterno. Nas convicções do orientalista, as generalidades ganham foros de verdade, e as listas especulativas sobre os orientais se aplicam aos orientais do mundo real: "[...] de um lado, temos ocidentais, no outro, árabes, os primeiros considerados pacíficos lógicos e liberais, e os últimos, não são nada disso" (Said, 2012, p. 85).

Nos dias atuais, veem-se pessoas, culturas e etnias sendo reprimidas, perseguidas por disputas econômicas que permanecem ditando a política de exploração e subjugo de várias regiões do planeta, sob o ideal da globalização. A sociedade atual tornou-se enormemente plural, cultural e religiosa. Isso se converteu em uma fonte de conflitos permanente. Berger (2017, p. 20) afirma sobre o pluralismo:

O pluralismo é uma situação social na qual pessoas de diferentes etnias, cosmovisões e moralidades, vivem juntas pacificamente e interagem amigavelmente. Esta última expressao é importante. Faz pouco sentido falar de pluralismo, quando as pessoas interagem, mas somente como senhores e escravos, ou quando elas vivem em comunidades fortemente segregadas e somente interagem em relações exclusivamente econômicas.

O fenômeno do fundamentalismo, diante do pluralismo e da ameaça globalizadora, reage afirmando a tradição e rejeita todo e qualquer engajamento dialogal com a modernidade. Em suas raízes há sempre o sentimento de insegurança, desorientação ou anomia resultantes de uma dinâmica modernizadora e, nesse sentido, parece constituir uma resposta para todas as frustrações da vida moderna. Para Prado (2010), foi no início na década de 70, com a Revolução no Irã, que o termo fundamentalismo religioso passou a ser associado a ações dentro do Islã, mas só depois de11 de setembro, quando ocorreu o ataque 
ao World Trade Center, nos Estados Unidos, que esse termo ressurgiu como uma categoria estigmatizante sobre um grupo específico.

É importante ressaltar que o termo fundamentalismo não é fácil de ser trabalhado, porque traz muitas generalizações, mas é de extrema importância trazê-lo para o contexto dessa pesquisa, já que é muito usado atualmente e aplicado à religião islâmica principalmente por causa dos reforços midiáticos ocidentais. Panasiewicz (2007, p. 51) pontua a respeito do conceito de fundamentalismo:

\begin{abstract}
O termo fundamentalismo tem sido vastamente utilizado nos últimos anos e muitas vezes de maneira imprecisa, pois tem servido para justificar atitudes religiosas fanáticas, um retorno à sociedade pré-moderna ou mesmo práticas violentas. É imprescindível que esse termo seja usado no plural, porque existem diferentes fundamentalismos. Se sua origem histórica se encontra no universo religioso, sua abrangência na sociedade atual ultrapassa esse universo e ocupa o espaço da política e da economia, carregando consigo um traço claramente ideológico. Ter consciência de sua pluralidade é resguardar as várias especificidades que o fenômeno vem produzindo
\end{abstract}

Pode-se afirmar que o fundamentalismo é considerado um movimento que nasce dentro da modernidade e que faz um contraponto dela, porque tenta resgatar raízes diante da instabilidade e da insegurança causadas por uma sociedade marcada pelo pluralismo e pelos princípios da modernidade, que questionam seu saber, sua identidade e seu poder. Não é uma doutrina, mas uma forma de interpretar e viver a doutrina. Prado (2013, p. 136) pontua que o levantamento histórico desde o surgimento do termo e a forma que é aplicado é considerado pejorativo, "[...] tanto no sentido de zelo pelos fundamentos ou de radicalismo o termo fundamentalismo desde sua origem traz uma carga de preconceito".

Giddens (2002) afirma, como visto, que com a modernidade surgem problemas, situações ligadas à identidade ou à crise dela. Os impactos da modernidade e da vida cotidiana geram dúvidas radicais e fontes de autoridade. Berger (2012) descreve que as comunidades precisam de um mínimo de identidade na interpretação da realidade, porque somente assim poderão desenvolver um papel sólido na geração e suporte de sentido da vida de seus membros. Quando as sociedades modernas são observadas, vê-se que se torna difícil a concordância com os processos de formação da identidade e de promover o convívio de sentido. Pode-se afirmar, assim, uma crise de sentido ou de identidade desses grupos, tanto para o mundo islâmico quanto para o mundo ocidental. Essa crise abre espaço para o fundamentalismo de ambos os lados, que pode ser lido como um exercício de reforço da identidade e que gera todo o sentido da vida. Com a entrada do ocidente no mundo islâmico houve reações, uma quebra na estrutura identitária do mundo muçulmano, uma crise de sentido. E em reação a essas crises de sentido surgirão as Reformas e, posteriormente, os grupos como a Al-Qaeda.

Para entender o surgimento dos movimentos radicais nos séculos $X X$ e $X X I$, é importante retomar as origens das reformas religiosas nos séculos XVIII e XIX no mundo muçulmano, como o Wahhabismo, criado por Mohamed ibnAbd al-Wahhab, e a corrente Salaffyyia, que defende o retorno estrito ao Alcorão e à Suna, que rejeita todas as interpretações divergentes. Já no século XX tem-se a "A Irmandade Muçulmana" , fundada por Hassan Al Banna, pensador egípcio influenciado pelos movimentos reformistas, que irá, por sua vez, influenciar a maioria dos movimentos islâmicos atuais.

Tanto o Wahhabismo quanto a corrente Salaffyya e, posteriormente, o grupo Irmandade Muçulmana, são movimentos fundamentais para entender o processo de formação de um pensamento que é utilizado por parte de grupos terroristas atuais, como, por exemplo, a Al-Qaeda. 


\section{Escolas e Reformas: a origem de um pe n s a m e n to}

Dentro do islã existem algumas linhas onde há um forte discurso sobre o retorno às tradições, relembrar o passado, trazer de volta os tempos do califado. Toda essa ideia de voltar ao passado é para que não aconteça a penetração de outras culturas e valores dentro da religião, as chamadas inovações fatos que ocorrem devido ao encontro de civilizações e culturas, efeitos do pluralismo e da globalização. Para entender o início de tudo, deve-se passar pelas ideias e escolas que antecederam a linha salafi dentro do islã e que remetem ao retorno das tradições e condenam as inovações.

Ahmed Ibn Muhammad Ibn Hanbal, conhecido como Ibn Hanbal, nasceu em Bagdá no ano de 780 (Hourani, 2013). Foi uma figura de grande importância na história islâmica e que dará origem à escola hanbalita. De acordo com o pensamento de Ibn Hanbal, não poderia haver qualquer questionamento ou discussão acerca do Alcorão ou dos hadiths. Não somente isso, Hourani (2013) alega que, de acordo com seu corpo de ideias, todas as decisões a serem tomadas deveriam estar de acordo com o Alcorão e a sunna do profeta Muhammad. Tudo aquilo que está escrito é visto integralmente como lei. Dessa forma, é fundada a escola hanbalita, umas das escolas e linhas de pensamento islâmica que rejeitavam todas as formas de intelectualismo teológico. Hanbal surge como peça-chave, criador desse corpo doutrinário (Hourani, 2013).

As ideias de Ibn Hanbal não eram apoiadas pela maioria, portanto ele sofreu rejeição devido ao seu conceito sobre o Alcorão, como aponta Al Matroudi (2006). Esse corpo doutrinário deixou adeptos, que darão um grande reforço às suas ideias. Entre esses adeptos e seguidores estava Ibn Taymiyya, nascido em 1263, na cidade de Harrān, entre a Síria e a Turquia dos dias de hoje. Taymiyya fazia parte da escola de jurisprudência hanbalita e, devido a esse fato, fazia uso de uma interpretação literal dos textos e rejeitava interpretações alegóricas ou metafóricas dos atributos divinos (Cherem, 2013).

Hourani (2013, p. 243) traz a importância de Taymiyya, agregada às idéias de Ibn Hanbal, para história islâmica:

Ibn Taymiyya desempenhou um papel importante na sociedade muçulmana de seu tempo,e depois da morte suas formulações da tradição hanbalita continuarm sendo um elementona cultura religiosa das regiões centrais islâmicas, mas em geral um elemento submerso, até que seu conhecimento foi ampliado no século XVIII por um movimento religioso que levou à criação do Estado saudita na Arabia central.

Dessa forma, foi esturuturada uma das escolas de pensamento sunita: a escola Hanbali. Tanto Taymiyya quanto Hanbal foram essenciais para reforçar as idéias de interpretações corânicas de Osama bin Landen, que retoma esses personagens em algum de seus escritos.

Baseado no retorno da tradição e na escola que sustenta o campo de idéias das Reformas, adentra-se a primeira delas: o Wahhabismo. Essa primeira reforma religiosa do século XVIII dará origem posteriormente à Salafyya. Foi criada por Mohamed ibn Abd al-Wahhab, que fez uma retomada ao Alcorão e à Suna, rejeitando a jurisprudência, o misticismo e também a filosofia medieval (Armstrong, 2009). Tentou criar uma fé pura baseada na primeira comunidade muçulmana no século VII e defendeu o retorno estrito ao Alcorão e à Suna, rejeitando todas as interpretações divergentes. Estabeleceu um Estado independente na região da Arábia central e do Golfo Pérsico. Durante esse período, havia sultões otomanos que divergiam dessa forma de pensamento colocado como islamismo original e, com isso, eram chamados de apóstatas, indignos da obediência dos fiéis e até merecedores da morte, aponta 
Armstrong (2009). Na tentativa de atrair novos adeptos, encontrou grande resistência por parte da elite religiosa e acabou sendo expulso de Basra e das cidades da Arábia central, sendo exilado no interior da Arábia. Fez aliança com o chefe tribal Muhammad IbnSa'ud e, dessa aliança surge o primeiro emirado saudita (Pinto, 2010).

O Wahhhabismo foi considerado um movimento agressivo pelo fato de ter sido imposto à população, "[...] fazendo uso também de técnicas rejeicionistas e violentas que serão usadas por reformadores fundamentalistas no século XX" (Armstrong, 2009, p. 73). Desde a fundação do reino da Arábia Saudita, em 1932, houve uma estreita relação entre os sauditas e a família governante com o Wahhabismo. Atualmente o Wahhabismo saudita contemporâneo combina os ensinamentos de seu fundador, Abd al Wahhab, e seus aspectos culturais. O Wahhabismo também é encontrado no Qatar, embora seja muito menos rigoroso (Blanchard, 2007).

Dentro do berço tradicional, tem-se também a forma de interpretar Salafi - que é onde encontram-se os grandes teóricos jihadistas da atualidade. Blanchard (2007) coloca que as crenças salafistas modernas cresceram em forma de um movimento para a reforma do final do século XIX e início do século $X X$, que surgiu em várias partes do mundo islâmico e que se desenvolveu progressivamente de forma conservadora.

Salaffyya ou Salafismo, de acordo com Pinto (2010), é um termo usado para designar correntes reformistas que procuravam resgatar a ideia de um islã dos "ancestrais" dos precursores (salaf), do profeta e seus companheiros. A ideia central do salafismo é o retorno às origens como forma de regenerar o islã, rejeitando inovações e adições que desvirtuam a mensagem do profeta Muhammad saws (saws significa: que a paz esteja com ele). Um ponto importante ressaltado pelo antropólogo Paulo Hilu é que o salafismo possuía diferentes correntes que dialogavam entre si, mas que nunca constituíram um movimento unificado, porque o significado de "origens" variava de acordo com o contexto cultural de cada país (Pinto, 2010). "As primeiras reformas surgiram na Índia, contra o domínio inglês. Outra corrente salafi surgiu em Bagdá durante o século XIX. E por fim a última em Damasco, em meados do século XIX, mas essa última foi diferente porque não rejeitou todas as práticas e doutrinas do sufismo" (Pinto, 2010, p. 138). Apesar do tradicionalismo conceitual, tinham uma concepção moderna sobre o texto sagrado como uma verdade objetivada e coerentemente codificada, afirma Pinto (2010).

Cherem (2010, p. 19, grifos do autor) esclarece a ligação entre o termo Wahhabismo com a Salaffyya:

Designa-se 'wahhabismo' o movimento religioso surgido na região central da Península Arábica (Najd), no século XVIII. O nome deriva de seu fundador, Muh.ammad ibn Abd al-Wahhâb (17031792). Seus seguidores rechaçam essa designação, definindo-se como salafiyyûn (sing.: salafi), ou seja, seguidores dos 'pios ancestrais' (salaf al-sâlih.). Os salaf eram compostos pelas três primeiras gerações de muçulmanos, que tiveram experiência direta do islã em seus tempos de glória e, portanto, são exemplos de conduta para os muçulmanos das gerações seguintes.

Cherem (2010) aponta, sobre os salafistas, que eles também se nomeiam "unitaristas" ou "monoteístas", ou ahl al-tawhîd "povo da unicidade de Deus". Em determinados casos, chamam-se simplesmente de "muçulmanos", em oposição a outros muçulmanos que não seguem a sua doutrina. Os salafis trazem em seu discurso uma restauração de um tempo, um retorno às tradições almejando um retorno aos antigos tempos do califado. Se colocam muitas vezes em discursos onde defendem a ideia de que são detentores da verdadeira vertente do islã. Porém, nem os termos referentes a eles são destinados unicamente a um povo; os termos salafie muwah.h.id também designam outros grupos, como os membros da religião drusa, derivada do xiismo ismaelita, como alega Cherem (2010). 
O Salafismo tem seu próprio método interpretativo no quesito retorno às fontes básicas do islã, que para eles é o Alcorão e a Tradição (sunna e h.adîth), tomados ao pé da letra (Cherem, 2010). O que torna o salafismo atrativo é que ele eleva o indivíduo acima de suas condições, sejam elas sociais ou políticas, ou de excluído e marginalizado. Com isso é criado um sentimento de força, que é usado como incentivo para buscar o conhecimento religioso (Cherem, 2010).

O salafismo, ao contrário do wahhabismo, é um fenômeno moderno, uma forma de asserção da identidade individual, uma reificação e conscientização da religião que transcende uma cultura específica (ao contrário, criando uma cultura transnacional). O salafismo eleva seu membro (homem ou mulher) a uma posição de superioridade e fortalecimento (Cherem, 2010, p. 29).

No século XX, para fechar a parte das Reformas, tem-se a Irmandade Muçulmana, um movimento Wahhabita fundado por Hassan Al Banna, como alega Pinto (2010), que propunha um movimento social que mobilizasse os egípcios em torno do Islã e criasse as bases da verdadeira liberdade. Esse movimento serviu de fundamento para grupos como a Al-Qaeda devido ao pensamento e teorias de Sayyid Qutb, que foi o segundo líder da Irmandade.

Hassan Al Banna, pensador egípcio nascido em 1906 no seio de uma família religiosa, na cidade de Al Mahmoudiyah, no oeste do Nilo, estudou, aos doze anos, uma escola de ensino em Damanhur. Em 1923 mudou-se para o Cairo para continuar seus estudos na faculdade Dar al-Ulum de formação de professores; formou-se em 1927 e foi promovido a professor na cidade de Ismaília. Além de pregar em mesquitas, Al Banna pregou também em cafés, para jovens que esqueceram os valores do Islã (Azoulay, 2015). Professor de escola secundária e tendo sido educado com base no sufismo e em estudos religiosos, Al Banna teve uma educação secular e moderna (Pinto, 2010). Em 1928, fundou, na cidade de Ismailiyya, ocupada na época pelo exército inglês, a Irmandade Muçulmana (Al Ikhwan al Muslimun). Tratava-se de uma associação político-religiosa a partir da qual propunha mobilizar os egípcios a fundar uma sociedade cuja lei fosse o Alcorão; ou seja, uma sociedade islâmica. Vale ressaltar que, para Al Banna, ver a cidade ocupada pelos ingleses suscitava nos corações dos patriotas amantes do próprio país uma sensação de mal-estar e um sentimento de vergonha (Azoulay, 2015).

Al Assar (2014, p. 5) sobre a relevância da Irmandade e de seu contexto de criação, diz que seus membros eram capazes de diagnosticar um enfraquecimento da sociedade islâmica, que foi asfixiada pela dependência e influência cultural vinda do Ocidente "[...] e de transformar um sentimento nacionalista anticolonial em uma ideia de restauração da comunidade muçulmana, a partir de um resgate dos valores islâmicos".

A Irmandade era marcada pela autenticidade cultural, que era expressa pelo Islã e se opunha à cultura estrangeira. Baseando-se em uma análise do que havia de errado nas sociedades muçulmanas, começaram um movimento pela reforma da moralidade individual e social. Além de considerar que o real estado islâmico seria aquele com as leis islâmicas, a sharia, Al Banna condenava divisões internas entre xiitas, sunitas Islã, propondo um Islã universal com a combinação do textualismo salafi e a espiritualidade sufi (Pinto, 2010). A partir da década de 1930, a Irmandade começou a ser disseminada pelo mundo árabe, com adeptos na Síria, Jordânia, Argélia e Marrocos. Segundo Hourani (2013), deve ser levada em conta, nos fins da década de 1930, a força política, na medida em que eles não se preocupavam somente com o Egito, mas sim com todo mundo islâmico.

No início da carreira política, Al Banna ainda não tinha elaborado um plano político, restringindo-se às ideias centrais do Islã (Moussali, 2018). A entrada efetiva na política começou quando, em 1941, a Irmandade apresentou candidatos para as eleições parlamentares, chegando, em 1949, a mais de dois 
mil escritórios em todo o Egito, com 600.000 membros ativos (Azoulay, 2015). Nesse momento, foi estabelecida também sua ala militar. Al Banna definiu a Irmandade não somente como uma organização política, mas também como uma sociedade cultural e uma associação atlética (Mitchel, 1969). Essa abordagem moderna incluía formas de lazer, participação política e prosperidade econômica, abrangendo, em função disso, atividades religiosas e devocionais, com círculos de leitura e discussão sobre os textos sagrados. Como, de acordo com Al Banna, para que acontecesse a unidade do Islã seria necessário que o Califado existisse, sendo a unidade dos muçulmanos se transcendendo, ele fez um chamado para repensar as questões políticas, razão pela qual a Irmandade fez o reavivamento islâmico. Al Banna acreditava que o governo islâmico moderno poderia ter várias formas, com novos exércitos, economia e organizações políticas.

Esse é o contexto, o da luta social e da resistência ao colonialismo, em que o nascimento do Islã político e da Irmandade Muçulmana deve ser colocado. Tanto em seus princípios quanto em suas ações, a organização permanece não-violentos até o início dos anos 60 . Slogans que invocavam o Alcorão como constituição, jihad como resistência ou martírio como ambição suprema. A ação deve ser entendida no contexto da luta anticolonial (Ramadan, 2012, p. 71).

Al Anani (2016) aponta que há especulações e afirmações de que Al Banna fundou unidades para preparar membros da Irmandade para o jihad, particularmente contra Israel, na década de 1940. Também acreditavam que esse sistema foi estabelecimento pelo Aparelho Secreto, a ala militar da Irmandade. De acordo com Azoulay (2015), Al Banna afirmava que o jihad era o outro elemento central que poderia ajudar a alcançar os objetivos que não foram alcançados com a da'wah (divulgação da fé).

Em 12 de fevereiro de 1949, Hassan Al Banna foi assassinado pelo serviço secreto egípcio, o que levou a Irmandade a viver na clandestinidade. Com a morte de Hassan, Sayyid Qutb, seguindo um caminho diferente, abriu um campo teórico e deu maior vigor à Irmandade, que, posteriormente, também influenciou o surgimento de movimentos políticos sociais de cunho radical.

Sayyid Qutb foi um crítico literário, poeta, ativista e militante nascido no Egito em 8 de outubro de 1906. Lutou por um Egito independente do colonialismo inglês e propôs a restauração da "Ummah" (nação islâmica), remetendo às ideias de Al Banna, com a constituição de um estado egípcio islâmico nos anos 50 e por acreditar no esgotamento do papel do homem ocidental e no desenvolvimento da humanidade tanto no campo material quanto no espiritual. De acordo com Santos (2009), o conceito de Ummah seria o sentimento de família, unidade, nação, dentro das práticas islâmicas. Para Qutb (1992, p. 10) "[...] é indispensável fazer ressuscitar esta nação, (ummah) enterrada sob os escombros das gerações, das crenças, e das atitudes".

Em 1948, o ministro o enviou aos Estados Unidos em uma missão de estudo, supondo que o conhecimento e o contato direto com a América iriam incliná-lo às políticas oficiais e induzi-lo a abandonar a política oposicionista (Qutb, 2006). As impressões de Sayyid Qutb sobre a América foram, em grande parte, negativas. Em Milestones ele ressalta isso e, quando observava as conquistas americanas na produção e organização social, Sayyid Qutb visualizou e enfatizou de forma incisiva o materialismo, o racismo e a permissividade sexual como características dominantes da nação americana (Qutb, 2006).

Kepel (2003) narra sobre os escritos de Sayyid Qutb e diz que ele se dirigia aos jovens nascidos após a independência e à que eles que não se beneficiavam da redistribuição da riqueza social, então tinha que se expressar de uma forma que eles conheciam. Criou uma escrita islâmica simples distante da complexa retórica dos ulemás, que era cheia de referências às tradições. Qutb se colocou no nível de seus leitores, se apoderou da comunicação política e a transformou em uma ferramenta de sua obra. 
Essas escolas de pensamento, como o Wahhabismo, Salaffya e o movimento Irmandade Muçulmana, de acordo com Pace (2005), fazem uma mobilização sociorreligiosa com uma nova base ética guerreira (jihad) contra povos vizinhos, penetração colonial e também por razões territoriais internas. Foram movimentos da mesma época e com alguns propósitos comuns, mas que em determinado momento se separam.

\section{Colonialismo, Reformas e um propósito: o Jih ad}

Um conceito importante que foi citado tanto pelos movimentos quanto pelas Reformas foi o jihad, que começou a ser mais ouvido depois dos atentados de 11 de setembro. De acordo com Cherem (2013), o conceito de jihad sempre esteve presente no islã, sobretudo depois dos atentados de 11 de setembro de 2001, quando a palavra jihad entrou no vocabulário corrente. Cherem (2013, p. 2) acrescenta: "A raiz j-h-d, de onde se origina, tem o significado geral de "esforço" ou "luta" (em inglês, geralmente traduzido como to strive, exert oneself, struggle). A palavra, em si só, nem sempre tem conotação religiosa. Tanto que pode ser até nome próprio masculino, inclusive cristão, no Oriente Médio".

Atualmente a palavra se tornou a base ideológica para o terrorismo, porém isso já acontecia na década de 1990 com alguns movimentos que se desdobraram e se tornaram uma forma de atividade islâmica radical. É importante frisar que o jihad não está inerentemente associado a crenças islâmicas puritanas. Entre muçulmanos puritanos - sejam eles auto descritos, salafistas ou wahhabis -, a defesa do jihad é um fenômeno relativamente recente e permanece altamente disputada dentro desses grupos (Blanchard, 2007).

Langer (2020) define jihad como um substantivo-verbal, sem plural, derivado da palavra jahada, que no léxico arábico significa esforço ou luta. É representada por diversas formas de esforço. Cook (2005) mostra que o termo jihad é dividido em três categorias de acordo com as formulações clássicas: jihad da mão (ou da espada), que era de natureza militar; jihad da língua, que envolvia a reprovação de um governante injusto ou de uma sociedade corrupta; e jihad da alma, desenvolvida principalmente pelos sufis, que envolvia travar uma batalha interna; uma luta contra a alma inferior.

Malashenko (2001) alega que as interpretações mais detalhadas do jihad vieram dos teólogos muçulmanos, e, dentro de uma interpertação popular, a jihad é dividida em quatro tipos:

Jihad Al nafs '(autoaperfeiçoamento)', jihad shaitani '(luta com o diabo)', Jihad al-kufar '(luta contra os infiéis)' e 'jihad al-munafikin' (luta contra os hipócritas). Além disso, eles diferenciam o 'jihad da língua', 'jihad da mão', especificamente aplicado ao conhecimento e conteúdo, e criando elementos do jihad maior (Malashenko, 2001, p. 6, tradução nossa)².

O conceito de jihad é dividido em categorias e varia de acordo com as vertentes islâmicas, como os sunitas e os xiitas, que interpretam o conceito de acordo com suas percepções da religião. Entre as maiores categorias de divisão do conceito,tem-se o jihad maior e ojihad menor. O jihad maior, com significado religioso, pode ser colocado como uma luta contra as tentações ("jihad do coração", "jihad da alma").

\footnotetext{
${ }^{2}$ In original: "'Jihad nafsii' (self improvement), 'jihad shaitani' (struggle with the devil), 'Jihad al-kufar' (struggle against the infidel), and 'jihad al-munafikin' (struggle against hypocrites). Moreover, they differentiate 'jihad of tongue', 'jihad of hand', having specific, appliedcontent, but making up elements of great jihad" (Malashenko, 2001, p. 6).
} 
Cherem (2009) pontua que a categoria possui uma abertura para o diálogo é abordada dentro de todo contexto islâmico.

Porém, aqui nesse ponto será trabalhado o conceito de jihad menor, que é abordado dentro do islã, que representa a defesa da fé e que se conecta com a guerra. Cherem (2009) coloca esse jihad como não menos importante, porque seria a defesa da religião e da fé. Além do direito de exercer a fé, essa categoria possui um último item, que é a luta em legitima defesa, caso o muçulmano se sinta ameaçado elou desrespeitado. Para Crone (2005, p. 367), o jihad era entendido pela maioria dos árabes tribais "[...] como um imperialismo árabe sob comando de Deus".

A história muçulmana começa com a hijira:a emigração de Muhammad para Medina, que não era uma cidade no sentido convencional, mas sim uma coleção de pequenas aldeias espalhadas pelo oásis, divididas politicamente entre duas tribos árabes pagãs (Cook 2005). Muhammad e os muçulmanos basearam sua comunidade em Medina e durante um período de cinco anos eles converteram os homens das tribos árabes que ocupavam o território. Cook (2005) aponta que foi dentro desse contexto que surgiu o jihad e as campanhas para ganhar adeptos e controle do território. As ações eram o foco da comunidade e da atividade do profeta Muhammad (saws) durante os seus últimos nove anos de vida.

Atualmente, baseados nessa parte do conceito, teóricos jihadistas buscaram suas interpretações para justificar seus atos. As Reformas e movimentos citados até o presente momento pensaram e teorizaram o jihad. O jihad conhecido hoje se baseia nos desdobramentos que esses teóricos promoveram desse conceito. Foi visto, sobre o período de colonização, que os muçulmanos não a aceitaram pacificamente, e pode-se dizer que todas as reações apresentadas são resultados das ações empregadas nesse período e até mesmo em um período anterior a ele. São resultados dos estereótipos, das políticas de desigualdade, do etnocentrismo e do silenciamento da cultura de um povo.

A comunidade imaginada e proposta pela Irmandade e a consolidação de um Estado islâmico podem ser lidas como uma relação de aproximação entre a tradição islâmica e a modernidade. No campo teórico oferecido pela Irmandade, as ideias de Al Banna e as de Qutb serviram de base para muitos personagens e grupos do Islã político, como Abdullah Azzam e Mohamed al Maqdisi (considerado o pai do jihad global e um dos teóricos mais influentes do meio na atualidade), e o mais conhecido, o grupo Al-Qaeda, criado por Osama bin Laden. Porém, é preciso ressaltar que esses viveram uma conjuntura diferente da vivenciada pela Irmandade, a qual estava respondendo às necessidades de seu contexto. Como passar dos anos, tomaram outra proporção, com outro corpo e outras ideias. Pode-se dizer, portanto, que cada movimento vive e responde às necessidades de sua época.

Sayyid Qutb, principal teórico que influenciou os demais teóricos citados acima, aponta que o jihad menor, no quesito jihad armado, é visto como necessário já que as outras possibilidades se esgotaram. O jihad passa a ser uma esperança de autonomia não somente econômica, mas também política e social (Qutb, 2006) e, acima de tudo isso, o resgate de uma identidade que eles alegam ter sido dizimada devido à colonização e toda a influência e forma de pensar ocidental.

No contexto de criação da Al-Qaeda, é importante salientar que as ideias de Qutb estiveram presentes desde o início da organização e que contou-se com a presença de outros personagens, fundamentais para o desenvolvimento teórico e armado da organização, que retomaram as ideias de Qutb. A formulação do grupo se deu através do encontro de Osama bin Laden com Abu Mohamed Maqdisi e Abdullah Youssef Azzam, ambos teólogos, filósofos palestinos com estudos acadêmicos voltados para a religião e que possuíam uma ligação direta com a Irmandade Muçulmana e com as obras de Sayyid Qutb.

Abdullah Azzam, foi professor de bin Laden quando este cursava a faculdade de engenharia. Azzam tinha uma formação na área de agricultura, porém resolveu posteriormente fazer uma faculdade voltada 
para a área religiosa, e foi nela que se desenvolveu, fez pós-graduações e elaborou seus escritos. Azzam já tinha tido contato com as obras de Qutb através da Irmandade Muçulmana, da qual ele passou a fazer parte em meados de 1950 (Winter, 2014).

Nas obras de Azzam são abordadas questões sobre o jihad e sobre uma luta pelas terras que foram tiradas dos muçulmanos devido à colonização. Para ele, o grande jihad seria uma falsificação; o ideal seria uma luta armada e a reconquista dos territórios. Azzam atuou como embaixador da causa afegã, onde teve contato com vários líderes locais (Schnelle, 2012). Ele discute sobre as diferentes facetas das decisões legais sobre o jihad, inclusive sob quais condições o jihad se torna uma obrigação para todos os muçulmanos. Inclui também uma discussão aprofundada sobre se os combates na Palestina e no Afeganistão devem ser considerados jihad (Schnelle, 2012).

Azzam apresenta oito razões para se juntar à luta no Afeganistão: (1) Para que os descrentes não dominem; (2) Devido à escassez de homens; (3) Medo do fogo do inferno; (4) Cumprir o dever do jihad e responder ao chamado do Senhor; (5) Seguir os passos dos Piedosos Antecessores; (6) Estabelecer uma base sólida como base para o Islã; (7) Proteger os oprimidos na terra; (8) Esperar o martírio e um alto posto no paraíso. Azzam (1989, p. 2) aponta: O pecado não é tirado do pescoço dos muçulmanos enquanto qualquer área de terra (que já foi muçulmana) "[...] permanece nas mãos de incrédulos, e ninguém será salvo do pecado, exceto aqueles que realizarem o jihad".

Atrelado também ao contexto da Irmandade Muçulmana e daqueles que beberam da fonte de Sayyid Qutb, tem-se o teórico pai do jihad salafi, o salafi Mohamed al Maqdisi.

Maqdisi estudou no Iraque durante a adolescência e também concluiu a faculdade de ciências, onde teve contato com a irmandade Muçulmana. Maqdisi, assim como Abdullah Azzam, foi também um grande influenciador de bin Laden e mentor espiritual de Zarqawi, que foi um dos líderes do movimento DAESH (Estado Islâmico), como alega Wagemakers (2009).

Esses personagens (Maqdisi, Azzam e bin Laden), juntamente com Ayman al Zawahiri, criaram um dos movimentos mais conhecidos do mundo; moderno e defensor da ideia de jihad global (por aceitar membros de vários países). Os teóricos, primeiramente, tiveram encontros separados com bin Laden, mas foi em um jantar não premeditado que os três se reuniram pela primeira vez e se identificaram nas ideias político-religiosas (Berger, 2012). Com a orientação paternal de Azzam, o talento retórico de bin Laden e o impressionante intelecto de Zawahiri, as sementes da Al-Qaeda foram plantadas (Murr, 2004). A Al-Qaeda, nesse sentido, surgiu através das ideias desses personagens, que foram influenciados por Qutb e começou a se formar na mesma época em que Azzam foi assassinado, aproximadamente em novembro de 1989.

Quando houve a formação do campo teórico do grupo, ficaram determinados os objetivos, que eram: a retirada das tropas americanas, acabar com as intervenções militares que matam os muçulmanos (em todo o mundo), a resolução da questão Palestina e, por fim, cessar o apoio a ditadores muçulmanos que colaboram com o ocidente (Cherem, 2009). Veem-se claramente, nos objetivos citados acima, as ideias e as mesmas indignações de Qutb, que almejava um país islâmico com autonomia e que respondesse por sua religião, sua política e economia.

Osama bin Laden, em uma de suas cartas, deixa claro suas ideias e suas percepções sobre o jihad:

Não existe maior dever, depois da fé, do que combater o inimigo atacante que corrompe a religião e o mundo. Deve opor-se-lhe a mais forte resistência possível, conforme prescrito pelos exegetas nossos companheiros e por outros (Taymiyya). O dever jurídico relativamente à Palestina e aos nossos irmãos que lá vivem - esses pobres homens, mulheres e crianças que não tem outro 
lugar para onde ir - é travar o jihad por amor a Deus e motivar a nossa ummah para o jihad de modo que a Palestina possa ser totalmente libertada e devolvida à soberania islâmica. A Palestina podia prescindir deste decreto jurídico, que desiste do jihad e deixa as coisas correrem, que aceita a ocupação inimiga dos locais mais sagrados para os muçulmanos depois dos dois Santuários Sagrados e que confere legitimidade à sua ocupação. O tipo de decreto que apóia plenamente as tentativas do inimigo de impedir os zelosos esforços islâmicos de libertar a Palestina por meio do jihad, que as operações dos heróis e da juventude do jihad islâmico na Palestina mostraram ser a única maneira útil de enfrentar o inimigo e garantir a libertação do país, Inshallah (se Deus quiser) (Lawrence, 2006, p. 23, grifos do autor).

Após os ataques de 11 de setembro, os objetivos se tornam conhecidos pelo ocidente e o líder da Al-Qaeda, em uma de suas cartas, declara jihad ao ocidente, principalmente, aos Estados Unidos, enumerando os motivos que explicariam seu pensamento e atitudes. Cherem (2009, p. 88), em seu artigo sobre o jihad, aponta, de maneira clara, as razões que levaram Osama bin Laden a declarar jihad ao ocidente:

[...] fato dos Estados Unidos serem um o país da opressão, mentiras, imoralidade, depravação, fornicação, intoxicação, apostas e usura; por estabeleceram a democracia e a Constituição no lugar da Lei de Deus; por explorem as mulheres como mercadoria; por fazerem do sexo uma indústria; porque espalham doenças devido a seu comportamento promíscuo; por destruírem a natureza e poluírem o meio-ambiente e mesmo assim não assinaram o Protocolo de Kyoto; por terem lançado as bombas atômicas de Hiroshima e Nagasaki; por terem dois pesos e duas medidas e agirem segundo seus interesses egoístas na política internacional; por não respeitarem o Direito Internacional; por não respeitarem os Direitos Humanos.

Nessa declaração é visível todo o ressentimento contra o ocidente, com todos seus atos, parcerias políticas, convicções. Na visão de Osama bin Laden, o ocidente é egoísta e se acha possuidor de uma única fonte de verdade, além de suas políticas pregarem a desigualdade (Cherem, 2009).

Após a morte de bin Laden, a Al-Qaeda passa a não recrutar somente os - fiéis; surgem também afiliados, como a Al Nusra -, que já era um dos braços da Al-Qaeda no Iraque. Assomam oportunistas, capitalistas da guerra, juntamente com membros de tribos pragmáticas com discursos comprometidos e que acabam tomando outra proporção, dando origem ao DAESH (Estado Islâmico) (Weiss; Hassan, 2015). Os mujahid (combatentes) que morreram durante a prática de seu jihad são nomeados mártires, se tornando exemplos para os que chegaram e incentivando a adesão daqueles que ainda não vieram (Qutb, 2006).

Osama bin Laden foi fundamental para disseminar as ideias de Maqdisi, Azzam e Qutb e, através de suas cartas e sermões, dava a certeza de que o jihad ao ocidente era o certo a se fazer. Bin Laden era um líder carismático e convincente. Devido ao seu carisma, após sua morte o grupo perde de vez sua centralidade e se divide em um número maior de células (Ramadan, 2012). De acordo com Ramadan (2012, p. 175, tradução nossa)³, a posição da Al-Qaeda é marginal, na melhor das hipóteses:

\footnotetext{
3 No original: The execution of the Al-Qaeda chief revealed once more the breadth of the chasm that separates the American administration from Muslims in the United States and around the world. Compared with the Western media, which played the event as a victory over the 'symbol of terrorism', reactions to bin Laden's death amongst Western and Eastern Muslims, not to mention in the Global South as a whole, were muted. The absence of images and of proof, the hasty disposal of the body at sea raised questions and reinforced doubts (Ramadan, 2012, p. 175).
} 
com a mídia ocidental, que jogou o evento como uma vitória sobre o - símbolo do terrorismo, reações a morte de Bin Laden entre muçulmanos ocidentais e orientais, para não mencionar o Sul Global como um todo, foram silenciados. A ausência de imagens e de provas, a disposição apressada do corpo no mar levantou questões e reforçou dúvidas.

Ramadan (2012) aponta que Osama bin Laden nunca comandou o respeito das massas e nunca galvanizou os corações dos povos muçulmanos (com exceção de uma minoria de extremistas violentos). Nisso, o governo americano provou mais uma vez o quão mal entende os corações e mentes muçulmanas. É importante frisar que pensamentos como os de bin Laden, Qutb, Maqdisi e Azzam representam a minoria, não retratando a totalidade da religião islâmica. O que esses personagens apresentam são suas interpretações e forma de viver a doutrina.

\section{Conclusão}

Vinte anos após os atentados de 11 de setembro e 10 anos após a morte de Osama bin Laden, entender o processo histórico o dia que marcou a história é fundamental. Conhecer o percurso teórico leva à reflexão e entendimento de que a ideia não surgiu de uma hora para outra; outros personagens haviam pensado e teorizado muito antes dos atentados. Osama bin Laden foi fundamental para divulgar as ideias dos teóricos; foi um líder que conseguiu expandir a Al-Qaeda através de seus discursos, que eram baseados em seus antecessores no campo de ideias.

O jihad de Quțb se desenvolveu em um período especifico e, independente da Irmandade ou de algum partido político, suas experiências pessoais colaboraram para o desenvolvimento de seu pensamento. Qutb conseguiu passar adiante a ideia de jihad como movimento e organizações independentes, o que muito inspirou jihadistas que vieram posteriormente em outras conjunturas. Azzam compartilhava a ideia de Qutb com relação à luta, seja ela individual ou em grupo, que tivesse como objetivo reconquistar as terras islâmicas. Uniu-se a outros teóricos, como Maqdisi e Osama bin Laden. O jihad global defendido por Azzam, Maqdisi e Osama bin Laden almeja derrubar os governantes ímpios dos países muçulmanos (baseado em uma visão anticolonial), criar um Estado islâmico lutar contra a injustiça e a corrupção. Todos citados já faziam parte do movimento salafista, que atualmente se apresenta crescente.

É de grande relevância ressaltar que esse campo de ideias apresentado pelos teóricos e por Osama bin Laden não representam a maioria dos muçulmanos; a guerra não é o objetivo do Islã. Esses personagens representam uma minoria, que está em um ramo especifico dentro da religião. Simultaneamente, quando ocorreram os atentados, milhares de muçulmanos foram mortos na Palestina, Afeganistão e Iraque antes, durante e depois dos atentados. Muçulmanos são mortos pelo exército americano, pelo israelense e até mesmo pelas mãos de outros muçulmanos. O ressentimento é algo que prevalece, juntamente com a sensação de injustiça e desigualdade - sentimentos que sustentam as ideias dos teóricos jihadistas citados.

O despertar árabe inicial almejou trazer uma mudança de perspectiva; algo que poderia sinalizar uma mudança no paradigma binário, porém cujos desdobramentos não compactuavam com as ideias iniciais (como, por exemplo, no caso da Irmandade Muçulmana e seu desdobramento, a Al-Qaeda).

De certo que tanto as sociedades do Oriente quanto as do Ocidente devem se comprometer com uma reforma para ajudar a fornecer respostas às crises que perseguem as sociedades modernas e para avançar em direção a uma boa convivência pluralista. A gestão do pluralismo religioso é fortalecida pela 
dinâmica interna das próprias religiões. Dessa forma, elas só podem existir e florescer em um espaço livre de restrições e com a ausência da imposição ou proibição. Não faz sentido falar de pluralismo quando as pessoas interagem, mas somente como senhores e escravos, com ambição de dominar, e quando vivem em comunidades fortemente segregadas e somente interagem nas relações de poder, exclusivamente econômicas.

Said adverte em "Orientalismo" de 2012, que a ideia de um choque de civilizações é um perigo constante e sem trégua e que somente a real vontade, o estudo de querer compreender o outro e sua cultura, sem a visão etnocêntrica e sem a ambição de dominar, poderia evitar tantos conflitos.

Por fim, foi apresentado esse contexto para trazer à tona e para conhecimento de todos o que existiu antes dos atentados, as relações que foram estabelecidas em um período anterior e que posteriormente resultaram em atos de terror. Esses atos são resultados dos estereótipos criados pelo ocidente referente aos muçulmanos, das políticas de desigualdade e, também, dos efeitos do pensamento imperialista e colonial.

\section{Referências}

Al Anani, K. Inside the Muslim Brotherhood: religion, identity, and politics. Oxford: Oxford University Press, 2016. Al Assar, S. R. A. A Irmandade Muçulmana: nação sob o cosmo islâmico. Rio de Janeiro: PUC-Rio, 2014.

Al Matroudi, A. H. The Hanbali school of Law and Ibn Taymiyyah. United States: Routledge, 2006.

Armstrong, K. O Islã. Rio de Janeiro: Objetiva, 2001.

Armstrong, K. Em nome de Deus: o fundamentalismo no judaísmo, no cristianismo e no islamismo. São Paulo: Companhia das Letras, 2009.

Azzam, A. Join the Caravan. Mecca: Maktabah Publications, 1989

Azoulay, R. The power of ideas: the influence of Hassan al-Banna and Sayyid Qutb on the Muslim Brotherhood organization. Israel: Przeglad Strategiczny, 2015.

Berger, P. L. Modernidade, pluralismo e crise de sentido: a orientação do homem moderno. Petrópolis: Vozes, 2012.

Berger, P. L. Os múltiplos altares da Modernidade. Petropolis: Vozes, 2017.

Blanchard, C. M. The Islamic Traditions of Wahhabism and Salafiyya. United States: Library of Congress,2007.

Cherem, Y. Jihad: duas interpretações contemporâneas de um conceito polissêmico. Campos, v. 10, n. 2, p. 83-99, 2009.

Cherem, Y. A crença, a lei, a guerra: uma análise do pensamento de 'Is.âmMuh.ammad T. âhir al-Barqâwî. Campinas: Unicamp, 2010.

Cherem, Y. Jihad: interpretações de um conceito polissêmico. História e Sociedade, v. 11, n. 2, p. 153-184, 2013.

Cook, D. Understanding Jihad. Berkeley: University of California Press, 2005.

Crone, P. God's Rule - Government and Islam: six centuries of medieval islamic political tought. New York: Columbia University Press, 2005

Giddens, A. Modernidade e identidade. Rio de Janeiro: Jorge Zahar, 2002.

Hourani, A. Uma história dos povos árabes. São Paulo: Companhia das Letras, 2013.

Kepel, G. Jihad. Paris: Editions Gallimard, 2003.

Lawrence, B. Mensagens ao mundo de Osama bin Laden. Lisboa: Temas e Debates, 2006.

Langer, J. Dicionário de história das Religiões na antiguidade e medievo. Petrópolis: Vozes, 2020.

Malashenko, A. Encyclopedia of jihad. Moscou: Faculty Publications and Presentations, 2001. 
Moussali, A. Hassan al-Banna. In: Sposito, J. L.; Shahin, E. El-D. Key islamic political thinkers. Oxford: Oxford University Press, 2018.

Murr, V. The power of ideas: sayyid Qutb and Islamism. Rockford: College Summer Research Project, 2004.

Pace, E. Sociologia do islã: fenômenos religiosos e lógicas sociais. Petrópolis: Vozes, 2005.

Panasiewicz, R. Pluralismo religioso contemporâneo: diálogo inter-religioso na teologia de Claude Geffré. São Paulo: Paulinas, 2007.

Pinto, P. G. H. R. Is/ã: Religião e civilização - uma abordagem antropológica. Aparecida: Editora Santuário, 2010.

Prado, P. S. Fundamentalismo religioso: uma análise sobre a religião no Islã e os desafios ao diálogo inter-religioso. In: Congresso Internacional SOTER, 23., 2010, Belo Horizonte. Anais [...]. Belo Horizonte, 2010.

Prado, P. S. O mundo nos nomeia: o fundamentalismo religioso no Islã e a categorização de uma identidade performativa. Belo Horizonte: PUC-Minas, 2013.

Qutb, S. Normas no caminho do Islã. São Paulo: Movimento da Juventude Islâmica Abu Bakr Assidik, 1992.

Qutb, S. Milestones. Birminghan: Maktabah Booksellers and Publishers, 2006.

Ramadan, T. Islam and the Arab awakening. Oxford: Oxford Press, 2012.

Said, E. W. Orientalismo. São Paulo: Companhia das Letras, 2012.

Santos, D. J. S. Ritual e performance na construção identitária da ummah islâmica. Revista Eletrônica de Ciências Sociais, v. 3, n. 6, p. 142-168, 2009.

Schnelle, S. Abdullah Azzam, ideologue of Jihad: Freedom Fighteror terrorist? Journal of Church and State, v. 54, n. 4, p. 625-647, 2012.

Teixeira, F. O pluralismo religioso e a ameaça fundamentalista. Numen, v. 10, n. 1, p. 9-24, 2007.

Wagemakers, J. A Purist Jihadi-Salafi: theideology of Abu Muhammad al Maqdisi. Cambridge: British Journal of Middle Eastern Studies, v. 36, n. 2, p. 281-297, 2009.

Weiss, M.; Hassan, H. Estado Is/âmico: desvendando o exército do terror. São Paulo: Seoman, 2015.

Winter, L. The Abdullah Azzam Brigades. Studies in Conflict \&Terrorism, v. 34, n. 1, p. 883-895, 2011. https://doi. org/10.1080/1057610X.2011.611935. 